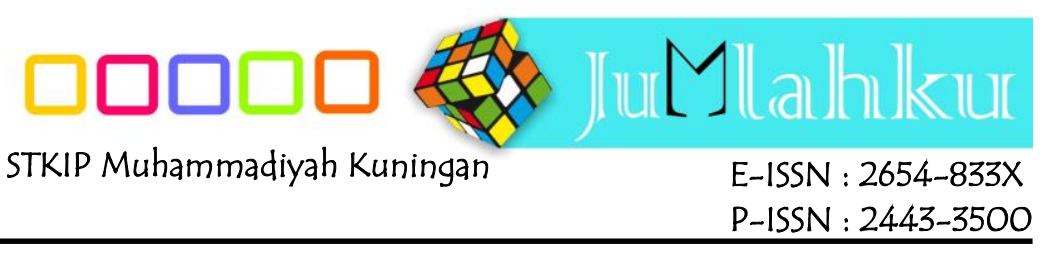

Jurnal Matematika Ilmiah STKIP Muhammadiyah Kuningan

Vol. 5 No.1 Mei 2019

P-ISSN : 2443-3500

\title{
FUZZY SISTEM: ESTIMASI HARGA NIKEL DUNIA
}

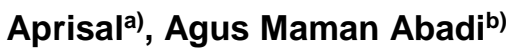

a) Pendidikan Matematika, FKIP Universitas Sulawesi Barat aprisalcicang@gmail.com

b) Matematika, FMIPA Universitas Negeri Yogyakarta agusmaman@uny.ac.id

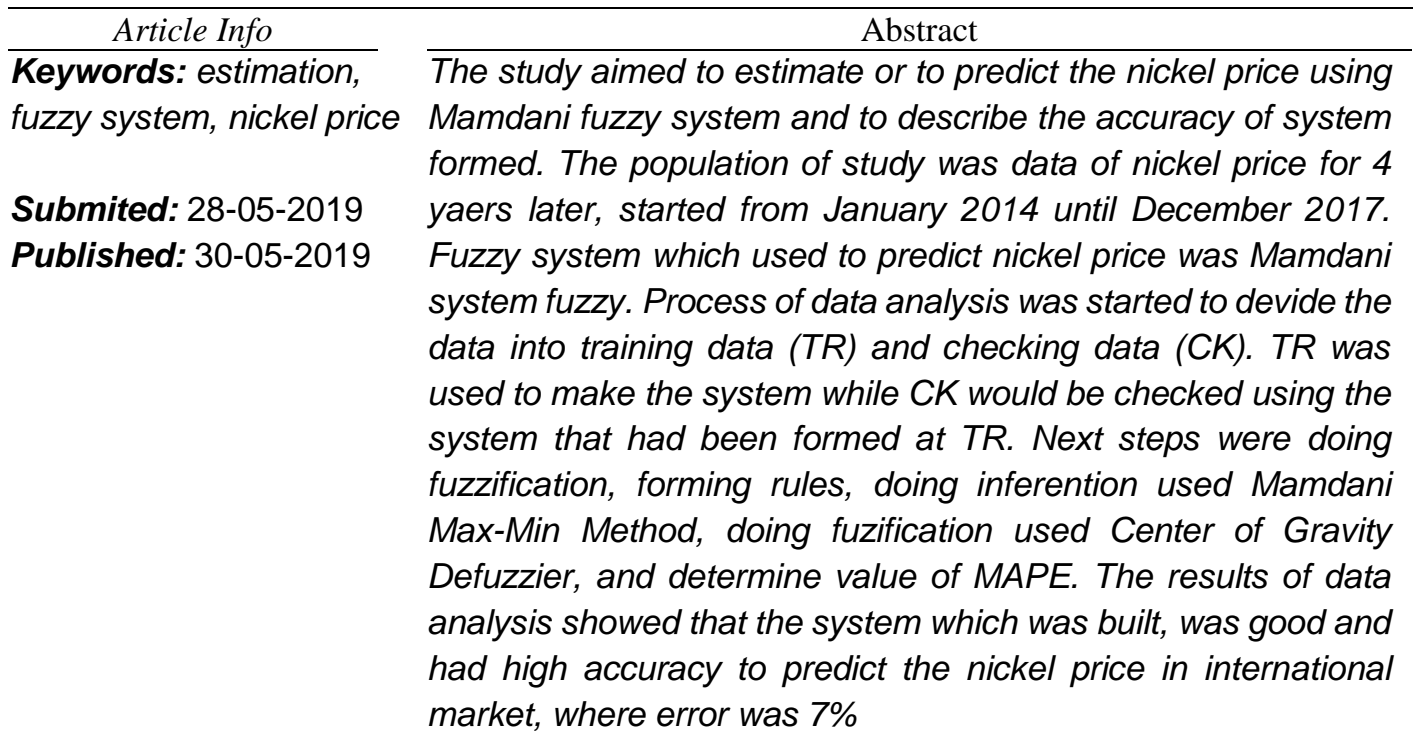




\begin{abstract}
Abstrak
Kata Kunci: estimasi, Penelitian ini bertujuan untuk mengestimasi atau memprediksi sistem Fuzzy, harga nikel harga nikel dunia menggunakan sistem fuzzy dan mengukur sejauh mana keakuratan sistem yang dibangun. Populosi pada penelitian ini adalah data harga nikel dunia 4 tahun terakhir yaitu data harga mulai Januari 2014 sampai Desember 2017. Sistem fuzzy yang digunakan untuk memprediksi harga nikel adalah metode Fuzzy Mamdani. Proses analisis data diawali dengan membagi data menjadi training data (TR) dan checking data (CK). TR digunakan sebagai data pembuat sistem, sedangkan CK adalah data yang akan diuji menggunakan sistem yang telah dibentuk pada TR. Langkah selanjutnya, proses yang dilakukan untuk memprediksi harga nikel dan menentukan tingkat keakuratan sistem yang dibangun yaitu melakukan fuzzifikasi, membentuk rule, melakukan inferensi dengan metode Mamdani Max-Min, defuzzifikasi dengan menggunakan Center of Gravity Defuzzier, dan menetapkan nilai MAPE untuk menentukan system error yang dibangun. Hasil analisis menunjukkan bahwa sistem yang dibangun sudah cukup baik untuk memprediksi harga nikel dengan error sebesar $7 \%$.
\end{abstract}




\section{PENDAHULUAN}

Nikel merupakan salah satu jenis unsur kimia yang berbentuk metal. Meskipun nikel merupakan unsur metal tetapi, nikel pada dasarnya berstruktur yang lembek dan mudah dibentuk. Pada sistem periodik unsur, nikel mempunyai lambang $\mathrm{Ni}$ dan memiliki nomor atom 28. Diketahui bahwa nikel merupakan salah satu elemen pembentuk inti bumi, di mana $10 \%$ di antaranya terbentuk dari nikel.

Di Indonesia sendiri, tersebar banyak tambang nikel dalam skala besar yang dioperasikan oleh perusahan-perusahaan internasional. Hal ini menjadikan Indonesia sebagai salah satu penghasil nikel terbesar kedua dunia setelah Rusia dengan menyumbangkan $15 \%$ dari jumlah produksi nikel pada tahun 2010 (Fitrian, Massiani, \& Maria, 2013). Salah satu daerah penghasil nikel terbesar di Indonesia terletak di Sorowako, Luwu Timur, Sulawesi Selatan. Salah satu unsur penting pada nikel yang ada di Sorowako adalah endapan laterit yang cukup melimpah. Hal ini telah dibuktikan oleh PT. Vale Indonesia dengan menambang dan mengolah dengan menggunakan teknik peleburan konvensional. Identifikasi endapan laterit yang merupakan unsur utama pada nikel berguna untuk menentukan langkah selanjutnya bagi perusahaan untuk melakukan penambangan skala besar secara komersil (Fitrian, Massiani, \& Maria, 2013). Endapan laterit tersebutlah yang akan diproses lebih lanjut, sehingga menghasilkan jenis nikel pig iron yang umunya dipakai pada produk-produk industri.

Pada kehidupan sehari-hari, nikel mempunyai banyak manfaat, terutama di bidang industri baja. Salah satu manfaat nikel yang paling utama adalah sebagai bahan campuran dalam pembuatan stainless steel (baja tahan karat).
Pembuatan berbagai barang di kehidupan sehari-hari dengan bahan utama besi, umumnya menggunakan campuran nikel. Hal ini disebabkan karena besi memiliki sifat kecenderungan mudah mengalami karat atau stain ketika mengalami osidasi. Dengan campuran nikel dan juga krom, maka dapat dibuat jenis besi yang tahan karat. Dalam industri transportasi, salah satu manfaat nikel sendiri adalah bahan baku pembuatan monel yang digunakan untuk membuat baling-baling pada kapal laut.

Dalam perdagangan nikel dunia, Indonesia sebagai salah satu penyumbang nikel terbesar dari jumlah produksi pertahun mempunyai peranan yang sangat strategis (Kumarawrman). Selain itu, adanya regulasi dan UU minerba yang dikeluarkan oleh pemerintah Indonesia turut mempengaruhi harga nikel di pasar dunia. UU No. 4 tahun 2009 yang kemudian terealisasikan pelaksanaanya pada Januari 2014, memberlakukan larangan ekspor bijih tambang mentah. Hal ini tentunya mempengaruhi harga nikel di pasar dunia di mana pada saat itu harga nikel merangsek naik dari USD 14.000/ton menjadi USD 18.000/ton. Kondisi tersebut tentunya membuat pusing konsumen nikel yang sebagian besar dikuasai oleh China dengan daya serap produksi nikel sebesar $51 \%$ dan kawasan Eropa sebesar 19,5\% dari kebutuhan nikel dunia (Kumarawarman). Namun demikian, meskipun telah diberlakukan aturan menurut UU No.4 tahun 2009, ekspor nikel di Indoensia tidak serta merta meninggalkan masalah. Hal ini disebabkan karena fasilitas dan sarana smelter yang ada di Indonesia belum cukup memadai. Akibatnya produksi dan harga nikel mengalami pasang surut menyesuaikan dengan perubahan regulasi yang ada. Melihat kondisi tersebut, 
perusahaan tambang nikel yang ada di Indonesia harus mampu memprediksi harga nikel dunia kedepannya sehingga produksi dapat disesuaikan dengan kebutuhan pasar.

Prediksi mempunyai peran yang cukup penting dalam memutuskan apa yang akan dilakukan (Sah \& Degtiarev, 2005). Memprediksi harga suatu barang termasuk tambang mineral membutuhkan analisis. Analisis sendiri terbagi atas dua yaitu analisis fundamental dan analisis teknikal. Analisis fundamental adalah analisis berdasarkan faktor yang secara langsung mempengaruhi harga, sedangkan analisis teknikal merupakan analisis yang didasarkan pada data yang diperoleh dari masa lalu, seperti harga, volume dan lainlain.

Banyak metode yang dapat dilakukan untuk melakukan prediksi, namun belum bisa memecahkan masalah prediksi dalam bentuk linguistik (Sah \& Degtiarev, 2005). Fuzzy time series memungkinkan untuk mengatasi masalah tersebut (Chen, 1996). Sistem fuzzy merupakan suatu sistem yang dibangun berdasarkan aturan dan pengetahuan diolah menggunakan fuzzifikasi, inferensi, dan defuzifikasi. Sistem fuzzy merupakan perluasan ilmu logika fuzzy. Teori logika fuzzy diperkenalkan oleh Zadeh pada sekitar tahun 1965. Logika fuzzy merupakan perkembangan dari logika klasik, di mana setiap elemen tidak dinyatakan benar atau salah, 0 atau 1, melainkan dengan derajat keanggotaan yang memiliki nilai 0 sampai 1 (Poongodi, dkk, 2012). Selanjutnya secara lebih khusus penelitian ini akan menggunakan Sistem Fuzzy Mamdani sebagai instrumen untuk memprediksi harga nikel.

Sistem Fuzzy Mamdani merupakan salah satu metode sistem fuzzy yang sering digunakan,] karena lebih intuitif dan sesuai dengan proses inputmanusia. Sistem Fuzzy Mamdani juga dikenal sebagai metode minmax, di mana fungsi implikasi yang digunakan adalah min dan komposisi aturan yang digunakan adalah max. Beberapa penelitian telah dilakukan dengan menggunakan sistem fuzzy dalam permasalahan berbasis data time series. Jayus Priyana dan Agus Maman Abadi (2011) memprediksi suhu udara Yogyakarta menggunakan model fuzzy dengan variabel input berupa data suhu udara sebelumnya, kemudian penelitian lain dengan memprediksi harga perak dengan metode mamdani menunjukkan bahwa tingkat kesalahan yang diperoleh untuk membangun sistem fuzzy sekitar 4\% (Ralmugis, Wahyudi, \& Abadi, 2016). Penelitian yang dilakukan oleh Chen dan Hsu (2004) tentang a new method to forecast enrollments using fuzzy time series, selanjutnya ada juga penelitian yang dilakukan oleh Alpaslan \& Cagcag (2012) tentang a seasonal fuzzy time series forecasting method based on gustafsonkessel fuzzy clustering. Berdasarkan penelitian sebelumnya dengan menggunakan data time series, baik untuk memprediksi maupun mengelompokkan data dengan menggunakan sistem fuzzy memberikan model yang akurat dengan tingkat kesalahan yang kecil, sehingga pada penelitian ini akan mengestimasi atau memprediksi harga nikel dunia menggunakan sistem fuzzy dan mendeksripsikan tingkat keakuratan model atau sistem yang dibentuk.

\section{METODE}

Penelitian ini bertujuan untuk mengestimasi atau mempredikasi harga nikel. Data yang digunakan merupakan data time series berjumlah 48 data, yaitu data 
harga nikel dunia per bulan mulai dari bulan Januari 2014 sampai bulan Desember 2017. Data tersebut diperoleh melalui https://www.indexmundi.com/commodities/ ?commodity=nickel\&months $=300$. Sebelum melakukan pemodelan, data dibagi menjadi dua bagian terlebih dahulu, yaitu training data (TR) dan checking data (CK). Pembagian data yang digunakan adalah $80 \%$ untuk TR dan $20 \%$ untuk CK dari keselurahan data harga nikel di dunia, sehingga dari 46 data yang terbentuk diperoleh 36 data sebagai TR dan 10 data sebagai CK. TR akan digunakan sebagai data pembuat sistem, sedangkan CK adalah data yang akan diuji menggunakan sistem yang telah dibentuk pada TR. Secara rinci prosedur untuk memprediksi harga nikel ditempuh melalui tujuh langkah:

a. Menentukan pasangan input-output

b. Menentukan himpunan universal

c. Menentukan fungsi keanggotaan himpunan fuzzy

d. Menentukan aturan fuzzy (rule)

e. Melakukan inferensi himpunan fuzzy dengan metode Mamdani

f. Melakukan defuzzifikasi dengan metode Center of Gravity Defuzzier

g. Menentukan MAPE sebagai pengukur besar kesalahan model

\section{HASIL DAN PEMBAHASAN}

Data yang digunakan untuk merancang sistem guna memprediksi harga nikel adalah data harga nikel dunia (USS Dolar) setiap bulan dengan satuan metric ton dari Januari 2014 sampai Desember 2017. Adapun datanya disajiakan pada Tabel 1 berikut.
Tabel 1. Harga Nikel

\begin{tabular}{|c|c|}
\hline Bulan & $\begin{array}{c}\text { Harga } \\
\text { (USS } \\
\text { Dolar) }\end{array}$ \\
\hline Training Data (TR) \\
\hline Jan-14 & 14101 \\
\hline Feb-14 & 14203 \\
\hline Mar-14 & 15678 \\
\hline Apr-14 & 17374 \\
\hline Mei-14 & 19401 \\
\hline Juni-14 & 18629 \\
\hline Juli-14 & 19118 \\
\hline Agust-14 & 18600 \\
\hline Sept-14 & 18035 \\
\hline Okt-14 & 15812 \\
\hline Nov-14 & 15807 \\
\hline Des-14 & 15962 \\
\hline Jan-15 & 14850 \\
\hline Feb-15 & 14574 \\
\hline Mar-15 & 13755 \\
\hline Apr-15 & 12831 \\
\hline Mei-15 & 13511 \\
\hline Juni-15 & 12825 \\
\hline Juli-15 & 11413 \\
\hline Agust-15 & 10386 \\
\hline Sept-15 & 9937 \\
\hline Okt-15 & 10317 \\
\hline Nov-15 & 9244 \\
\hline Des-15 & 8708 \\
\hline Jan-16 & 8507 \\
\hline Feb-16 & 8298 \\
\hline Mar-16 & 8717 \\
\hline Apr-16 & 8879 \\
\hline Mei-16 & 8660 \\
\hline Juni-16 & 8928 \\
\hline Juli-16 & 10263 \\
\hline Agust-16 & 10336 \\
\hline Sept-16 & 10192 \\
\hline Okt-16 & 10260 \\
\hline Nov-16 & 11129 \\
\hline Des-16 & 10972 \\
\hline Jan-17 & 9971 \\
\hline
\end{tabular}




\begin{tabular}{|c|c|}
\hline \multicolumn{2}{|c|}{ Checking Data (CK) } \\
\hline Mar-17 & 10205 \\
\hline Apr-17 & 9609 \\
\hline Mei-17 & 9155 \\
\hline Juni-17 & 8932 \\
\hline Juli-17 & 9491 \\
\hline Agust-17 & 10890 \\
\hline Sept-17 & 11216 \\
\hline Okt-17 & 11336 \\
\hline Nov-17 & 11972 \\
\hline Des-17 & 11495 \\
\hline
\end{tabular}

Data yang menjadi TR dan CK tersebut dipasangkan menjadi pasangan inputoutput. Pada penelitian ini variabel input adalah data harga nikel pada bulan-bulan sebelumnya yaitu data pada waktu $T-2$ dan $T-1$. Sedangkan variabel output-nya yaitu data harga nikel pada waktu $T$. Setelah ditentukan pasangan output input, diperoleh data maximum yaitu 19401 dan data minimum yaitu 8298 sehingga ditentukan himpunan universal berada pada interval [8000 20000].

Data yang menjadi input dan output pada penelitian ini mempunyai fungsi keanggotaan yang sama dan dibentuk dengan menggunakan fungsi keanggotaan segitiga. Adapun banyaknya himpunan fuzzy untuk input dan output ada sebanyak 9, yaitu himpunan fuzzy harga nikel sangatsangat rendah sekali $\left(A_{1}\right)$, himpunan fuzzy harga nikel sangat rendah sekali $\left(A_{2}\right)$, himpunan fuzzy harga nikel sangat rendah $\left(A_{3}\right)$, himpunan fuzzy harga nikel rendah $\left(A_{4}\right)$, himpunan fuzzy harga nikel sedang $\left(A_{6}\right)$, himpunan fuzzy harga nikel tinggi $\left(A_{6}\right)$, himpunan fuzzy harga nikel sangat tinggi $\left(A_{7}\right)$, himpunan fuzzy harga nikel sangat tinggi sekali $\left(A_{8}\right)$, dan himpunan fuzzy harga nikel sangat-sangat tinggi sekali $\left(A_{9}\right)$. Fungsi keanggotaan pasangan data input-output dapat dilihat persamaan berikut.

$$
\begin{aligned}
& \mu_{A_{1}}(x)=\left\{\begin{array}{l}
\frac{9500-x}{1500} ; 8000 \leq x \leq 9500 \\
0 ; x \geq 9500
\end{array}\right. \\
& \mu_{A_{2}}(x)=\left\{\begin{array}{l}
\frac{x-8000}{1500} ; 8000 \leq x \leq 9500 \\
\frac{11000-x}{1500} ; 9500 \leq x \leq 11000 \\
0 ; x \leq 8000 \text { atau } x \geq 11000
\end{array}\right. \\
& \mu_{A_{3}}(x)=\left\{\begin{array}{c}
\frac{x-9500}{1500} ; 9500 \leq x \leq 11000 \\
\frac{12500-x}{1500} ; 11000 \leq x \leq 12500 \\
0 ; x \leq 9500 \text { atau } x \geq 12500
\end{array}\right.
\end{aligned}
$$$$
\mu_{A_{4}}(x)=\left\{\begin{array}{l}
\frac{x-11000}{1500} ; 11000 \leq x \leq 12500 \\
\frac{14000-x}{1500} ; 12500 \leq x \leq 14000 \\
0 ; x \leq 11000 \text { atau } x \geq 14000
\end{array}\right.
$$$$
\mu_{A_{5}}(x)=\left\{\begin{array}{l}
\frac{x-12500}{1500} ; 12500 \leq x \leq 14000 \\
\frac{15500-x}{1500} ; 14000 \leq x \leq 15500 \\
0 ; x \leq 12500 \text { atau } x \geq 15500
\end{array}\right.
$$$$
\mu_{A_{6}}(x)=\left\{\begin{array}{l}
\frac{x-14000}{1500} ; 14000 \leq x \leq 15500 \\
\frac{17000-x}{1500} ; 15500 \leq x \leq 17000 \\
0 ; x \leq 14000 \text { atau } x \geq 17000
\end{array}\right.
$$$$
\mu_{A_{7}}(x)=\left\{\begin{array}{l}
\frac{x-15500}{1500} ; 15500 \leq x \leq 17000 \\
\frac{18500-x}{1500} ; 17000 \leq x \leq 18500 \\
0 ; x \leq 15500 \text { atau } x \geq 18500
\end{array}\right.
$$$$
\mu_{A_{8}}(x)=\left\{\begin{array}{l}
\frac{x-17000}{1500} ; 17000 \leq x \leq 18500 \\
\frac{20000-x}{1500} ; 18500 \leq x \leq 20000 \\
0 ; x \leq 17000 \text { atau } x \geq 20000
\end{array}\right.
$$$$
\mu_{A_{9}}(x)=\left\{\begin{array}{c}
\frac{x-18500}{1500} ; 18500 \leq x \leq 20000 \\
0 ; x \leq 20000
\end{array}\right.
$$

Berdasarkan fungsi keanggotan di atas, maka diperoleh grafik himpunan fuzzy pada input-output sebagai berikut. 


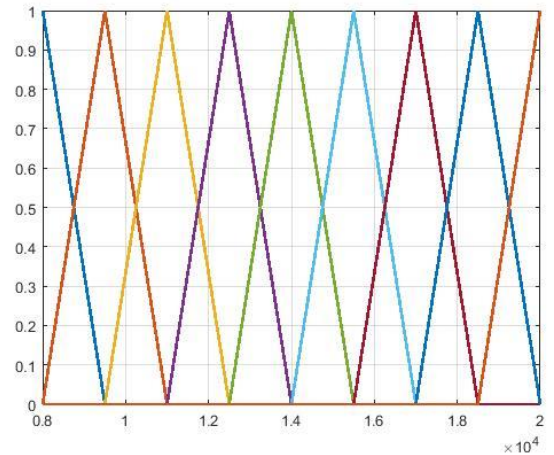

Gambar 1. Himpunan Fuzzy Input-Output
Setelah melakkukan fuzzifikasi dengan membentuk pasangan input-output pada data, maka langkah yang paling penting adalah pembentukan aturan (rule). Aturan (rule) dibentuk untuk menyatakan hubungan antara data input dan data output. Rule yang dibentuk menggunakan operasi $A N D$ untuk menghubungkan dua input, sedangkan relasi input dan output dibentuk dengan menggunakan aturan IFTHEN. Misalnya pada pasangan input dan output yang pertama dihasilkan rule sebagai berikut.

"jika $T$-2 adalah A1 dan $T-1$ adalah $A 1$, maka $T$ adalah $A 1$ "

Pada tahap ini dihasilkan rule sebanyak 36 berdasarkan input dan output data. Adapun rule yang terbentuk disajikan pada Tabel 2 berikut.

Tabel 2. Rule yang Terbentuk

\begin{tabular}{|c|c|c|c|c|c|c|c|}
\hline \multirow{3}{*}{$\begin{array}{c}\text { RULE } \\
\text { KE- }\end{array}$} & \multicolumn{3}{|c|}{ RULE } & \multicolumn{3}{c|}{ DK } & \multirow{2}{*}{ DK } \\
\cline { 2 - 7 } & \multicolumn{2}{|c|}{ INPUT } & OUTPUT & \multicolumn{2}{c|}{ INPUT } & OUTPUT \\
\cline { 2 - 6 } & $T-2$ & $T-1$ & $T$ & $T-2$ & $T-1$ & $T$ & \\
\hline
\end{tabular}

\begin{tabular}{|c|c|c|c|c|c|c|c|}
1 & $\mathrm{~A} 1$ & $\mathrm{~A} 1$ & $\mathrm{~A} 1$ & 0,53 & 0,66 & 0,8 & 0,27984 \\
\hline 2 & $\mathrm{~A} 1$ & $\mathrm{~A} 1$ & $\mathrm{~A} 1$ & 0,66 & 0,8 & 0,52 & 0,27456 \\
\hline 3 & $\mathrm{~A} 1$ & $\mathrm{~A} 1$ & $\mathrm{~A} 2$ & 0,8 & 0,52 & 0,59 & 0,24544 \\
\hline 4 & $\mathrm{~A} 1$ & $\mathrm{~A} 2$ & $\mathrm{~A} 1$ & 0,52 & 0,59 & 0,56 & 0,171808 \\
\hline 5 & $\mathrm{~A} 1$ & $\mathrm{~A} 2$ & $\mathrm{~A} 3$ & 0,56 & 0,62 & 0,51 & 0,177072 \\
\hline 6 & $\mathrm{~A} 2$ & $\mathrm{~A} 1$ & $\mathrm{~A} 1$ & 0,83 & 0,53 & 0,66 & 0,290334 \\
\hline 7 & $\mathrm{~A} 2$ & $\mathrm{~A} 1$ & $\mathrm{~A} 2$ & 0,59 & 0,56 & 0,62 & 0,204848 \\
\hline 8 & $\mathrm{~A} 2$ & $\mathrm{~A} 3$ & $\mathrm{~A} 2$ & 0,71 & 0,54 & 0,83 & 0,318222 \\
\hline 9 & $\mathrm{~A} 2$ & $\mathrm{~A} 3$ & $\mathrm{~A} 3$ & 0,62 & 0,51 & 0,56 & 0,177072 \\
\hline 10 & $\mathrm{~A} 2$ & $\mathrm{~A} 3$ & $\mathrm{~A} 3$ & 0,54 & 0,51 & 0,91 & 0,250614 \\
\hline 11 & $\mathrm{~A} 3$ & $\mathrm{~A} 2$ & $\mathrm{~A} 1$ & 0,54 & 0,83 & 0,53 & 0,237546 \\
\hline 12 & $\mathrm{~A} 3$ & $\mathrm{~A} 2$ & $\mathrm{~A} 3$ & 0,56 & 0,54 & 0,51 & 0,154224 \\
\hline 13 & $\mathrm{~A} 3$ & $\mathrm{~A} 2$ & $\mathrm{~A} 3$ & 0,98 & 0,69 & 0,76 & 0,513912 \\
\hline 14 & $\mathrm{~A} 3$ & $\mathrm{~A} 2$ & $\mathrm{~A} 3$ & 0,59 & 0,71 & 0,54 & 0,226206 \\
\hline 15 & $\mathrm{~A} 3$ & $\mathrm{~A} 3$ & $\mathrm{~A} 2$ & 0,72 & 0,59 & 0,71 & 0,301608 \\
\hline 16 & $\mathrm{~A} 3$ & $\mathrm{~A} 3$ & $\mathrm{~A} 2$ & 0,51 & 0,56 & 0,54 & 0,154224 \\
\hline 17 & $\mathrm{~A} 3$ & $\mathrm{~A} 3$ & $\mathrm{~A} 2$ & 0,91 & 0,98 & 0,69 & 0,615342 \\
\hline
\end{tabular}




\begin{tabular}{|c|c|c|c|c|c|c|c|}
18 & A3 & A3 & A3 & 0,51 & 0,91 & 0,98 & 0,454818 \\
\hline 19 & A4 & A3 & A3 & 0,78 & 0,72 & 0,59 & 0,331344 \\
\hline 20 & A4 & A5 & A4 & 0,78 & 0,67 & 0,78 & 0,407628 \\
\hline 21 & A5 & A4 & A3 & 0,67 & 0,78 & 0,72 & 0,376272 \\
\hline 22 & A5 & A4 & A5 & 0,84 & 0,78 & 0,67 & 0,438984 \\
\hline 23 & A5 & A5 & A4 & 0,62 & 0,84 & 0,78 & 0,406224 \\
\hline 24 & A5 & A5 & A6 & 0,93 & 0,86 & 0,88 & 0,703824 \\
\hline 25 & A5 & A6 & A7 & 0,86 & 0,88 & 0,75 & 0,5676 \\
\hline 26 & A6 & A5 & A5 & 0,57 & 0,62 & 0,84 & 0,296856 \\
\hline 27 & A6 & A6 & A5 & 0,69 & 0,57 & 0,62 & 0,243846 \\
\hline 28 & A6 & A6 & A6 & 0,72 & 0,79 & 0,69 & 0,392472 \\
\hline 29 & A6 & A6 & A6 & 0,79 & 0,69 & 0,57 & 0,310707 \\
\hline 30 & A6 & A7 & A9 & 0,88 & 0,75 & 0,6 & 0,396 \\
\hline 31 & A7 & A9 & A8 & 0,75 & 0,6 & 0,91 & 0,4095 \\
\hline 32 & A8 & A6 & A6 & 0,69 & 0,72 & 0,79 & 0,392472 \\
\hline 33 & A8 & A8 & A6 & 0,93 & 0,69 & 0,72 & 0,462024 \\
\hline 34 & A8 & A8 & A8 & 0,91 & 0,59 & 0,93 & 0,499317 \\
\hline 35 & A8 & A8 & A8 & 0,59 & 0,93 & 0,69 & 0,378603 \\
\hline 36 & A9 & A8 & A8 & 0,6 & 0,91 & 0,59 & 0,32214 \\
\hline
\end{tabular}


Pada Tabel 2 di atas, diperoleh beberapa rule yang memiliki input (anteseden) yang sama dan menghasikan output (konsekuen) yang sama pula. Pada rule yang lain diperoleh juga beberapa rule yang memiliki input (anteseden) yang sama tetapi menghasikan output (konsekuen) yang berbeda. Dengan demikian, pada kedua kasus tersebut maka dilakukan reduksi rule dengan memilih rule yang mempunyai derajat keanggotaan yang paling tinggi, sehingga diperoleh 18 rule hasil direduksi . Hasil reduksi rule dapat dilihat pada Tabel 3 berikut.

Tabel 3. Reduksi Rule

\begin{tabular}{|c|c|c|c|}
\hline \multirow{2}{*}{$\begin{array}{c}\text { RULE } \\
\text { KE }\end{array}$} & \multicolumn{2}{|c|}{ IF } & THEN \\
\cline { 2 - 4 } & \multicolumn{2}{|c|}{ INPUT } & OUTPUT \\
\cline { 2 - 4 } & $T-2$ & $T-1$ & $T$ \\
\hline 1 & A1 & A1 & A1 \\
\hline 2 & A1 & A2 & A3 \\
\hline 3 & A2 & A1 & A1 \\
\hline 4 & A2 & A3 & A2 \\
\hline 5 & A3 & A2 & A3 \\
\hline 6 & A3 & A3 & A2 \\
\hline 7 & A4 & A3 & A3 \\
\hline 8 & A4 & A5 & A4 \\
\hline 9 & A5 & A4 & A5 \\
\hline 10 & A5 & A5 & A6 \\
\hline 11 & A5 & A6 & A7 \\
\hline 12 & A6 & A5 & A5 \\
\hline 13 & A6 & A6 & A6 \\
\hline 14 & A6 & A7 & A9 \\
\hline 15 & A7 & A9 & A8 \\
\hline 16 & A8 & A6 & A6 \\
\hline 17 & A8 & A8 & A8 \\
\hline 18 & A9 & A8 & A8 \\
\hline & & & \\
\hline 18
\end{tabular}

Berdasarkan Tabel 3 di atas, maka dapat disusun eskpresi atau bahasa linguistik dari setiap rule sebagai berikut.

1. Jika harga nikel pada dua bulan sebelumnya sangat-sangat rendah sekali dan harga nikel pada bulan sebelumnya sangat-sangat rendah sekali, maka harga nikel pada bulan ini sangat-sangat rendah sekali.

2. Jika harga nikel pada dua bulan sebelumnya sangat-sangat rendah sekali dan harga nikel pada bulan lalu sangat rendah sekali, maka harga nikel pada bulan ini sangat rendah. Dstnya

Ekpresi linguistik hasil reduksi rule di atas dapat dilanjutkan sampai rule yang ke-18.

Selanjutnya, setelah terbentuk rule dari hasil reduksi, maka untuk memprediksi harga Nikel dunia adalah Inferensi Mamdani. Inferensi Mamdani menggunakan fungsi implikasi min dan komposisi antar aturan max. Pada fungsi implikasi min akan diambil nilai minimum himpunan fuzzy dari setiap aturan yang digunakan. Pada proses tersebut dengan menggunakan sampel pada aturan data ke-14 diperoleh 0,16 pada himpunan fuzzy $A_{5}, 0,38$ pada himpunan fuzzy $A_{5}$ dan 0,62 pada himpunan fuzzy $A_{6}$. Pada tabel di atas untuk himpuan fuzzy $A_{5}$ terdapat dua nilai komposisi aturan, sehingga dipilih yang maksimum yaitu 0,38 . Hasil komposisi aturan kemudian digunakan untuk membentuk fungsi keanggotaan daerah fuzzy. Fungsi keanggotan daerah hasil yang terbentuk melalui inferensi minimum sebagai berikut.

$$
\mu_{(y)}=\left\{\begin{array}{cc}
\frac{y-12500}{1500} & ; 12500 \leq y \leq 13070 \\
0,38 & ; 13070 \leq y \leq 14570 \\
\frac{y-14000}{1500} & ; 14570 \leq y \leq 14930 \\
0,62 & ; 14930 \leq y \leq 16070 \\
\frac{17000-y}{1500} & ; 16070 \leq y \leq 17000
\end{array}\right.
$$

Fungsi keanggotaan fuzzy yang diperoleh dari proses inferensi kemudian diproses menggunakan defuzzifier untuk dijadikan bilangan tegas. Bilangan tegas yang akan 
diperoleh, merupakan hasil prediksi harga nikel pada $T$. Defuzzifier yang digunakan adalah defuzzifier centroid dengan rumus sebagai berikut.

$$
y^{*}=\frac{\int_{V} y \mu_{B^{\prime}}(y) d y}{\int_{V} \mu_{B^{\prime}}(y) d y}
$$

Berdasarkan hasil defuzzifier diperoleh prediski harga nikel dunia yang ditunjukkan pada Gambar 2 berikut.

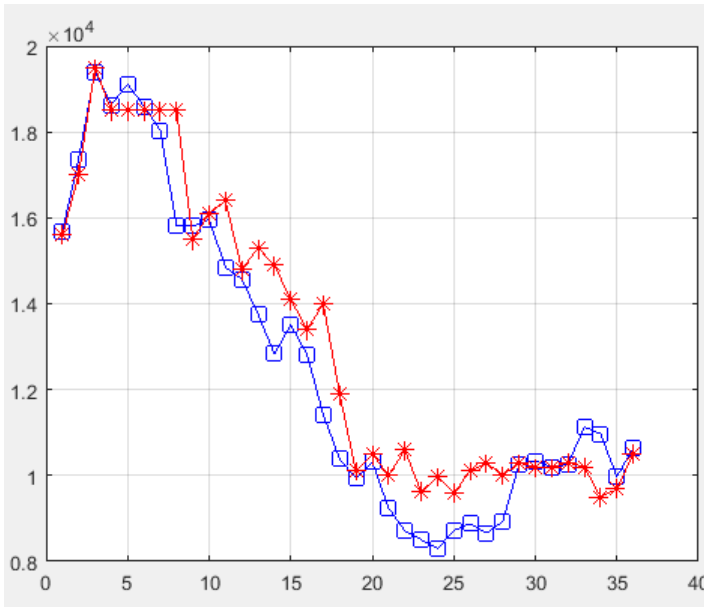

Gambar 2. Plot Data Asli dan Data Prediksi

Selain itu, hal yang penting dalam membangun sebuah sistem adalah menentukan sejauh mana keakuratan model atau sistem yang dibangun. Mengukur keakuratan model berarti menentukan sebesar besar kemungkinan kesalahan (error) pada model tersebut. Untuk menentukan error model/sistem pada penelitian ini menggunakan MAPE (Mean Absolute Percentage Error). Untuk menentukan nilai MAPE, maka akan dihitung jumlah nilai absolut error untuk semua data, kemudian bagi nilai absolut error tersebut dengan banyaknya jumlah data. Berdasarkan hasil perhitungan diperoleh error sebesar 0,07 atau $7 \%$.

\section{PENUTUP}

\section{Simpulan}

Berdasarkan penelitian di atas, untuk memprediksi harga nikel dunia tidak hanya bergantung pada faktor-faktor yang secara langsung mempengaruhinya tetapi juga dapat menggunakan data time series berupa data harga nikel pada bulan-bulan sebelumnya. Memprediksi harga nikel dengan menggunakan data time series dapat ditempuh dengan langkah-langkah di antaranya: menentukan pasangan input-output, menentukan himpunan universal, menentukan fungsi keanggotaan himpunan fuzzy, menentukan aturan fuzzy (rule), melakukan inferensi himpunan fuzzy dengan metode mamdani, melakukan defuzzifikasi dengan metode center of gravity defuzzier, menentukan mape sebagai pengukur besar kesalahan model. Pada penelitian ini, diperoleh error sebesar 0,07 atau 7\% yang berarti bahwa model yang dibangun mampu memprediksi dengan baik perkembangan harga nikel dunia dengan tingkat kearutan model sebesar $93 \%$.

\section{DAFTAR PUSTAKA}

Alpaslan, F., \& Cagcag, O. 2012. A seasonal fuzzy time series forecasting method based on gustafson-kessel fuzzy clustering. Journal of Social and Economics Statistics. 1(2): 1-13.

Chen, Sm., M. (1996). Forecasting enrollments based on fuzzy time series. Fuzzy Sets and Systems. 8(1): 311-319.

Chen, S., M., \& Hsu, C., C. 2004. A new method to forecast enrollments using fuzzy time series. International Journal of Applied Science and Engineering. 2(3): 234-244.

Fitrian, E., B. Massiani, M., A. \& Maria. 2013. Identifikasi sebaran nikel laterit 
dan volume bijih nikel daerah Anoa menggunakan korelasi data bor. Jurnal ELL.

https://www.indexmundi.com/commoditie $\mathrm{s} /$ ?commodity $=$ nickel\&months $=300$ diunduh pada 5 Januari 2018.

Kumarawarman, B, "Dunia tambang nikel indonesia: kemana angin berhembus?," Diunduh dari https://www.iagi.or.id/dunia-tambangnikel-indonesia-kemana-anginberhembus.html, pada tanggal 10 Jnauari 2017.

Mu, W., Zhai, Y., \& Liu, Y. 2010. Leaching of magnesium from desliconization slag of nickel laterite ores by carbonation process. Trans Nonferrous Met. Soc. 20: 87-91.

Pan, C., X., Lv., BaiC., LiuX. D, Li, Min, J. 2013. Meltingfeaturesand viscosityOfSi- O2-Cao-MGO-Al2O3feOnnickelslag inlateritemetallurgy. J. Min. Metall. Sect. B-Metall. 49(1): 912.

Poongodi, M., Manjula, L., Pradeepkumar, S., \& Umadevi, M. 2012. Cancer prediction technique using fuzzy logic. International Journal of Current Research. 4(2): 106-110.

Priyana, J., \& Abadi, A., M. 2011. Peramalan suhu udara di yogyakarta dengan menggunakan model fuzzy. Diunduh dari eprints.uny.ac.id/7149/1/M-31\%20\%20Jayus\%20Priyana.pdf pada tanggal 10 Januari 2017.

Qui, W., Zhang, C., \& Zhang, P. 2015. Generalized fuzzy time series forecasting model enhanced with particle swarm optimization. International u- and e- Service, Scince and Technology. 8(5): 129-140.

Ralmugis, U., Wahyudi, E., \& Abadi, A., M. 2016. Application of fuzzy system for predicting sliver price. $4^{\text {th }}$ Icriems Proceedings 2017.
Sah, M. \& Degtiarev, K., Y. 2005. Forecasting enrollment model based on first-order fuzzy time series. Proceedings of World Academy of Science, Engineering and Technology. 1(1): 375-378 